\title{
Work as a route out of homelessness: a case study of Emmaus Communities
}

\author{
Anna Clarke* \\ University of Cambridge
}

\section{Summary}

There is currently a strong emphasis in UK housing policy on and tackling the links between worklessness and housing. Helping or incentivising people into work is increasingly seen as a way of helping them to address their own housing difficulties, including street homelessness.

Emmaus Communities have been operating worldwide for over 60 years and in the UK since 1992. They offer a distinctive approach to helping people out of homelessness, in which the role of work and community living are central. This paper examines the effectiveness of this approach and asks what lessons can be learned for wider housing and worklessness policy in the UK and elsewhere. It finds that, though not suitable for all, Emmaus Communities show that even some of the most marginalised homeless people can benefit from work. They also highlight the complementary and interdependent nature of work, housing and relationships in addressing severe social exclusion.

Keywords: Homelessness, Worklessness, Single homeless, Emmaus, Hostels.

\section{Introduction}

There is currently a strong emphasis in UK housing policy on and tackling the links between worklessness and housing. Helping or incentivising people into work is increasingly seen as a way of helping them to address their own housing difficulties, including street homelessness. This paper offers some evidence from a review of Emmaus Communities to explore the links between worklessness and housing. It first examines the current thinking in terms of addressing worklessness and homelessness. It then draws on a case study of Emmaus Communities to explore some of the links identified. It asks what aspects of work it is that might help people to move out of homelessness. Who benefits from this kind of approach? Why might working help? And are there times when it might not? 


\section{Emmaus Communities}

Whilst there is a wide variety of Emmaus projects worldwide, the core model is one of selffinancing communities within which residents (known as 'companions') live and work together. They employ a social enterprise model; in the UK most communities operate businesses based around reselling second-hand furniture and goods.

\section{Research Methods}

This research is based on case studies of two Emmaus Communities:

- a study of Cambridge Emmaus, undertaken in 2004 (Lovett et al, 2004)

- a study of Emmaus Village Carlton undertaken in 2008 (Clarke et al, 2008).

Both communities accommodate around 30 formally homeless men and women. A total of 53 semi structured interviews were carried out with 21 'companions', nine staff members, seven volunteers, eight local referral agencies and three trustees. Staff at five other Emmaus Communities were also interviewed. In addition administrative data was drawn upon for both Emmaus Village Carlton and Emmaus UK (the umbrella body) covering data compiled from Emmaus Communities throughout the UK. The qualitative data from the interviews was analysed inductively using Nvivo software, allowing a grounded theory approach to identifying the mechanisms by which work might be helping people to move out of homelessness.

\section{Understanding Homelessness and Worklessness}

Much of the literature around homelessness, both policy and academic, has tended to focus on the causes of homelessness with debate between individual or structural causes. There has however, developed an increasingly sophisticated understanding of interaction between these two - to include the role of individual agency. An increasing emphasis on life course and "homeless careers" (Anderson and Christian, 2003; Anderson and Tulloch, 2000; Clapham, 2003; MacKenzie, 2003; May, 2000) has developed though often still with an emphasis on routes into homelessness, rather than out of it.

Macknee and Mervyn, (2002) have built on this kind of framework in their analysis of "critical incidents" for understanding how people move away from homelessness. They identified discovering some measure of self-esteem; achieving mainstream life goals, accepting personal responsibility and changing perceptions as three key factors favouring successful move-on. These are also aspects that could be closely related to employment.

There has been substantial recent political focus on worklessness in the UK, which has several distinctive aspects:

It encompasses a wider range of people in different situations than the term unemployed (Richie et al, 2005). Those in receipt of incapacity benefit have been a particular focus (Dorsett, 2008; Leeds Metropolitan, 2007; Nickell, 2004). 
There is a concern with long-term removal from the labour market and upon workless households where no one has a job, rather than individuals (Hasluck and Green, 2005; Nickell, 2004).

There is also a growing emphasis on neighbourhoods with high levels of worklessness (DCLG, 2007; Dewson et al, 2007; Sanderson, 2006), out of concern that a "culture of worklessness" can develop when particular neighbourhoods have high levels of worklessness (Dewson et al, 2007; Gregory, 2009; Richie et al, 2005; Sanderson, 2006). Individuals who are further from the world of work, or whose family and social contacts too are outside of the workforce may experience a more enduring worklessness (Ritchie et al, 2005; Leeds Metropolitan, 2007; DCLG, 2007) and find it harder to find and to sustain work.

It is also known that homeless people often have multiple other difficulties, such as drug or alcohol problems, mental health difficulties, chronic physical health problems, a learning disability, a history of institutionalization (such as prison, care, armed services), involvement in crime or prostitution. There are substantial overlaps between these differing forms of exclusion (Feldman, 2006, Mohan, 2002; Paylor, 1995; Percy-Smith 2000; Stein et al, 2000) indicating the presence of cumulative disadvantage amongst many of the homeless population.

The links have also been made more broadly with social housing not just with homelessness. It is clear that the lack of a job highly constrains housing options, but it has also been argued that living in poor quality housing, and particularly in social housing in poor neighbourhoods worsens people's chances of moving into work (Feinstein et al, 2008; Gregory, 2009).

Whilst it is clear that most homeless people lack jobs, the relationship between homelessness and worklessness is neither one-directional nor straightforward.

\section{Policy Responses to homelessness}

Unlike families, single homeless people in the UK are generally reliant on support or accommodation provided by the voluntary sector, albeit funded largely though statutory funding streams (Housing Benefit to cover the housing costs of provision, and Supporting People funding to meet the costs of housing-related support).

It is widely acknowledged that many homeless people have additional difficulties which may also need to be addressed if they are to sustain housing (Jones and Pleace, 2005; ODPM, 2003; Pleace, 2008; Smith et al, 2008). However, there has also been a recent emphasis on a 'Housing first' approach whereby those with substantial difficulties are given accommodation first, and then helped to address their other difficulties (Atherton and McNaughton; Nicholls, 2008). This is part of a wider move to allow homeless people to move directly into self-contained accommodation, with support as needed and thereby to avoid the problems some encounter with hostel-type accommodation (which has traditionally been the main type of accommodation offered to those in immediate need of housing). There is, however a continued acknowledgement of the role of hostels and other types of non-self-contained housing for some people (Fitzpatrick et al, 2000). 


\section{Policy responses to worklessness}

The current government's agenda for tackling worklessness is explicit that nearly everyone of working age should in work or seeking work (DWP, 2010). Support and help to find work are being made available but those of working age who are capable now or in the future of any work are to be required to fulfil their responsibilities in making themselves ready for work and seeking it (ibid). Radical reforms to the welfare regime have built upon those introduced by the previous administration (DWP, 2008) seeking to introduce greater incentives to work and cut welfare expenditure especially on workless adults of working age.

Given the profile of the homeless population, these reforms will mean that many will now be expected to enter the job market or will be penalised if they don't.

This political interest in worklessness has lead to a plethora of studies examining what is known to work in tackling worklessness (ERS, 2005; Hasluck and Green, 2007, Leeds Metropolitan, 2007; Meadows, 2006; Sanderson, 2006). Overall studies have concluded that most programmes have most success with those who are closest to the labour market, noting that it is considerably harder to help those with multiple difficulties and problems (Fletcher et al, 2008; Sanderson, 2006). Services have been shown to work best when tailored to individual needs, rather than the needs of generic groups (Hasluck and Green, 2007; Leeds Metropolitan, 2007; Sanderson, 2006).

Emmaus Communities are in a sense job-creation schemes. There is overall little evidence to support the use of direct job-creation schemes to target area-based problems (Meadows, 2006; Sanderson, 2006), though there is more support for intermediate labour markets targeted at individuals (such as many Emmaus Companions) who need support to sustain work (Marshal and Macfarlane, 2000; Meadows, 2006; Sanderson, 2006).

\section{The new holism}

The previous government increasingly recognised the complex nature of the links between housing and work (CLG, 2008) and 'tackling worklessness' was one of the four key objectives of the recent Enhanced Housing Options programme: "Bringing housing and employment advice together is one way to tackle worklessness among those in housing need and in the next generation of social tenants." (CLG, 2008: 12).

There has also been concern for some time over the very high levels of economic inactivity amongst people living in hostels (FEANTSA, 2007; Singh, 2005). This has led to a growing interest within the voluntary sector in providing accommodation that is conditional on being in education or paid work such as the Foyer movement (Quilgars and Anderson, 1997).

The focus of the labour government during the late 1990s and 2000s included a move to frame housing as something that should be conditional on working, or at least seeking work (Gregory, 2009; Hills, 2007). Interest increased in schemes (such as the large development of Kings Cross Station in Camden, and some of the schemes operating under the Enhanced Housing Options) where being in work is a prerequisite of acquiring a tenancy. The current government has taken up vigorously the links between work and housing, as part of ethos of conditional welfare (HM Treasury, 2010); ending security of tenure for social tenants and reducing housing benefit payments to working age households who are out of work. 
Overall, there is therefore a strong policy focus expecting participation in the workforce from key groups who have been outside of it for some time. There is also an increasing interest in making housing support conditional on working. Emmaus Communities offer an interesting chance to explore how they two may interact, and what role living in a supported community may play in helping people with long histories of worklessness back into the workforce.

\section{Emmaus Communities}

Emmaus Communities in the UK are open to single men and women aged over 18. There is an open-door philosophy and a belief that no one should be permanently banned or turned away if there is space. The vast majority of companions are homeless (or about to become so) when they come to Emmaus. Most have been without stable accommodation or work for many years. Some have never worked previously. Overall, the majority of companions are aged over 25. Nearly all are white and the vast majority (around 95 per cent nationally) are men.

\section{Work histories}

Although from a wide range of backgrounds, the research found that Emmaus companions could be divided into two broad categories, older people who have at some point in the past had stable lives, often with a family, home and job but at some point have lost this all. In many cases this followed bereavement, often accompanied by heavy drinking, job loss, and/or debt problems. In some cases it was years later that this group found their way to Emmaus, having spent time previously in hostels, night shelters or sleeping rough. Few had formal qualifications or had remained at school after the age of 16.

The second group were younger and often without any previous work experience. Both drink and drug problems (including heroin) were common in this group. Most wanted to work but had encountered numerous difficulties in finding or sustaining employment without a settled home.

Overall, around half of those interviewed were claiming Jobseekers Allowance. The rest were generally claiming Incapacity Benefit, in some cases with an element of Disability Allowance, in recognition of various health problems.

The main reason for difficulties in finding and sustaining work were the lack of structure to life on the streets, or even in a hostel. Day to day survival tended to take priority. In addition alcohol, drug and mental health problems all tended to be compounded by homelessness and make it impossible to either find or maintain employment.

\section{Does working at Emmaus help people move out of homelessness?}

There are two aspects to this question. The first is whether the approach taken in Emmaus provides in itself an opportunity for people to benefit from working, to contribute to society and improve their quality of life whilst they stay in the Emmaus Community. The second is whether it acts in a stepping stone, helping people move on into paid employment and independent housing in the wider world. 
There seems substantial evidence that, as an end in itself, working within an Emmaus Community does add value to people's lives. Most of the agencies who refer people to Emmaus held it in high esteem and knew of people who'd done well there, who they'd seen fail elsewhere:

The stability and regime that Emmaus offers is geared perfectly to rehabilitating people on every level, socially, financially, physically and emotionally. I don't think a lot of them would get jobs otherwise. (Day Centre)

The nature of the work itself could potentially increase the sense of purpose for those involved.

In terms of whether working at Emmaus rehabilitates people and equips them for living in the outside world, the evidence is more mixed. It seems this may be a factor that varies a great deal between Emmaus Communities. Some have a much greater emphasis on move-on as an ultimate goal (even if it may take several months or even years to achieve). Others hold dear the view that living and working in an Emmaus Community is an end in itself and a valid life-choice. There is real conflict between these two philosophies. Those favouring an emphasis on move-on argue that Emmaus cannot serve the interests of the wider community, and a constant demand for places unless it can move people on who no longer need to be there. There was also some concerns expressed that long-term companions come to be relied on as the basis for a stable community without much thought as to whether they need to be there.

I've sorted myself out I think I don't just want to be just working here for 36 pounds a week....And like when I asked the staff here like how do I get to move on from here, they just said that like after a six months or so we'll put your name on the list, for housing associations or the council... just think that now I'm ready to go back out there. (Companion)

In contrast, others argue that living and working in an Emmaus Community should be recognised as a valid life choice, and that for some people it might be the only way in which they can live a meaningful and stable life as they would never cope well with life in "normal" society.

I still don't think I'd survive in the outside world. Because I know that I would most probably end up back on the drink. Because out there I wouldn't have the kind of support I have here. (Companion)

Some Emmaus Communities have experimented with move-on and those sorts of things. The difficulty for Emmaus Communities is that it deflects from their primary purpose, which is to exist as a Community. That is the end is itself. (Staff member)

This last quote points to a tension within communities between these two objectives; an emphasis on move-on as the ultimate outcome can undermine the sense of independence and self-worth of others who are not able to function well outside of a supporting community such as Emmaus.

Emmaus Communities vary in their successes in moving people on to independent living. Some Communities could think of very few people who'd successfully moved on in the previous year. Staff at Emmaus Village Carlton, however, could name 12 (out of 38) 
p.95. Work as a route out of homelessness: a case study of Emmaus Communities

who had left over the past 12 months who were known to have gone on to a job and independent housing. In addition, six others left to live with family or friends without a job. Given that no one we interviewed had had a job in the 12 months prior to moving in, and that almost all were homeless, this does suggest some measure of success in rehabilitating people and equipping them for independent living.

\section{Identifying how work is benefiting people}

This section explores the impact and possible benefits that work appears to have on the Emmaus Companions.

Financial

Emmaus companions receive only a pocket-money level wage ( $£ 36$ a week, plus food, accommodation and other expenses), so there are no substantial financial benefits to most people who could otherwise claim state benefits. Indeed, for some previously in receipt of Incapacity Benefit or Disability Living Allowance, they may in fact be worse off financially at Emmaus. Financial benefits were mentioned only by one companion interviewed for this research, so the overall conclusion must be that the financial benefits of working at Emmaus therefore insignificant for most.

In the longer term, those who move on to paid employment outside Emmaus did benefit financially. Companions who left Emmaus village Carlton generally went into manual jobs such as labouring or catering. Given that these were single people with no dependents, this would usually represent a substantial increase on benefit levels, even after tax and housing costs.

There are therefore no real financial benefits to companions whilst working at Emmaus, but a potential future benefit if Emmaus is considered as a stepping stone to future independence.

\section{Psychological}

The companions interviewed were asked how they found their work within the Emmaus Community. For many, this was their first opportunity to work, or their first for many years. A few were explicit about the benefits they felt they'd gained from working in terms of their sense of self-worth:

I find, especially when new ones come in, they want to talk to me because l've been here for such long time, and they ask me for advice. When before no-one ever asked me for that!

You've got a job to do as well so you get some dignity back.

However, most were more inclined to emphasise that they simply enjoyed the work:

Emmaus is a best place anyone could ask for. You can do all different thing, like clothing, work in the restaurant, brick a brack, work on bikes, work in the shop, it's brilliant. You get a chance to do everything. 
p.96. Work as a route out of homelessness: a case study of Emmaus Communities

The benefit of work that companions were most likely to articulate was that of having a fixed pattern and routine to their day particularly by those with a history of drug or alcohol use:

Prior to moving in here I think the alcohol was getting more and more. When you're on the street you've got to drink to get to sleep. Emmaus has helped me through that...It's the work. Just getting up in the morning really. Can't do that if you're drinking.

Development of skills

Some Emmaus Communities put considerable effort into training courses, often focused on computing and basic literacy. However, it would appear from the jobs taken by those who moved into work that that computer skills were not often needed; of the 12 companions who left Village Carlton with a job, one was a kitchen porter, one a barman, four went into manual labouring, two into catering, two into paid employment within Emmaus Communities, two into casual work and one to work in a bakery.

There were also examples given of companions who had developed skills and interests in electronics whilst at Emmaus and gone on to qualify as electricians. It would seem that the skills, and perhaps more importantly interests, developed at Emmaus did in some cases lead to future employment opportunities.

Social

A few companions were explicit about the social benefits of working. The nature of Emmaus as a community was emphasised by many as giving meaning to their work and their lives:

I get on with the other companions all right. I've made a load of new friends since I have been here...Having a good team, having a good bunch, and making this place work like clockwork. It's them, it's them really.

The geographical isolation of both the Cambridge and Bedford Emmaus Communities was mentioned by some as a beneficial factor who appreciated the opportunity to be away from "the scene", where peer group influences encouraged drinking and drug-taking.

However, the difficulties in living and working with others, was also the most commonly cited difficulty for Companions at Emmaus. Falling out with others was also a common reason for leaving.

\section{Who benefits from this approach?}

Having established whether and how this approach might be working, it is important to consider who it works for.

The first, and most obvious, factor is that it is only aiming to cater for the single homeless population over the age of 18 . It is also not really an approach designed to address youth homelessness and relatively few under $25 \mathrm{~s}$ are accommodated despite this group composing a large part of the single homeless population (Fusco, 2005). 
In terms of ethnicity, Emmaus appears to cater for a largely white client group. In Emmaus Village Carlton, all 29 companions at the time of the research were white. Given that research has found households from ethnic minority groups are roughly three times more likely to be statutorily homeless than White British people (Gervais and Rehman, 2005), and the proportion of non-white people in Bedford is around 26 per cent (Census, 2001), the ethnic profile of companions at Emmaus Village Carlton could be regarded as unexpected.

In terms of gender, men appear to comprise the majority of single homeless people in most settings. The Government's review of Supporting People funding found that around 30 per cent of funding for "Single homeless with support" went to women (Fusco, 2005). This is, however, considerably more than the proportion of women at Emmaus, which is nationally around five per cent. Reasons for this are unclear, though referral agencies noted that homeless women they dealt with were more likely than men to be suffering from substantial mental health problems that would make Emmaus an unsuitable option for them. The age profile may also play a part. It is also possible that the culture that emerges within an Emmaus Community, offers a kind of peer support particularly beneficial for men:

I like living here. Before, I used to be pretty angry, but to be amongst guys, be amongst people again....

Beyond age, gender and ethnicity, the research sought to explore whether there was a "type" of person to which the Emmaus approach was particularly suited. Referral agencies were asked whether they felt there was a particular type of individual who suited Emmaus. Similarities between agencies in the descriptions of the suitable characteristics for potential companions, suggests a form of informal filtering process may take place. There were some common themes. Agencies reported having not referred people who they believed or knew to be unwilling or unable to work. Many companions struggled with getting along with their fellow workers, and a few found that the demands of working 40 hours a week were extensive, when trying to deal with other problems or not in a good state of mental health.

I just needed to, I suppose, distress. And I don't think I have been able to do that. I think if anything I'm more stressed now than I was before."

Some also found that, whilst the Community itself could be a strong source of support, it could be difficult being physically isolated from wider society and without a car.

Sobriety is also deemed crucial. All agency representatives who were interviewed for the purposes of this project admitted that they avoid referring people to Emmaus if their substance abuse problems had not yet been sufficiently addressed.

All interviewed representatives of agencies that refer companions to Emmaus made the point that perhaps it is not so much whether a person has an addiction problem or not but whether they are willing to address that problem.

The structured days and sense of purpose and responsibility that Emmaus is seen to offer were also considered to be particularly beneficial for people who have offended in the past and are at a high risk of re-offending, and people who have very little formal education and work experience. 
Emmaus enables a lot of people to take the first step into working life in a less intimidating way than if they tried it straight from here - they get skills and therefore confidence. (Probation Officer)

The stability and regime that Emmaus offers is geared perfectly to rehabilitating people on every level, socially, financially, physically and emotionally. (Day Centre)

Several agencies reported that Emmaus could be very suitable for people with mild learning difficulties. For them, Emmaus is often one of the few possible avenues to employment of any kind, especially if they have a history of homelessness and lack familial support networks.

It would also seem from the companions themselves that Emmaus was particularly suited to those with experience of, or a liking for, communal living; a substantial number of companions had previous experience in the army or navy. However, these groups are overrepresented in the single homeless population at large, so it is hard to be sure to what extent they are over-represented at Emmaus from a sample of this size.

The groups for whom Emmaus communities in their current form seem less suitable would include women, young people and ethnic minorities. It is, however, possible that these groups could benefit from this kind of approach, in a setting where they able to enjoy more peer support and feel less of a minority. Homeless women have been shown to be put off by all-male settings (Reeve et al, 2006).

There are also some groups for whom the Emmaus approach is unlikely to work: The most chaotic street-homeless people are not at a stage when they can benefit from this kind of approach dependent on being able to work five days a week, though some do come to Emmaus at a later stage, possibly via a stay in a hostel or detox. There are also many known cases of companions leaving after fall-outs, often brought on by the stress of communal living and working. This kind of lifestyle does not suit everyone.

The approach also suits only those who are able to work. Emmaus Communities are currently facing a situation where some of their long-term companions are reaching retirement. Their need for the community, and of course for housing, has not diminished, but their ability to work will at some point do so.

\section{Discussion}

Emmaus Communities show clearly that some people with multiple difficulties and who haven't worked for years can sustain 9-5 work if given the right support. And some of these, after a period of time, are capable of moving on into conventional paid work and independent living. Tacking worklessness often involves an analysis of "distance from the work force" with those being out of work for a short time, with educational qualifications and life skills being considered more likely to get back to work in a short time, whereas those with additional difficulties such as addictions, homelessness and health problems are known to be much harder to get back into work. Using this framework, the companions at Emmaus would largely be classed as being at some distance from the workforce yet their experience shows that work need not be an end-goal after dealing with other problems but can give valuable routine and structure to a chaotic lifestyle alongside support to address 
other difficulties; Emmaus could in a sense be termed both a 'housing first' and a 'work first' approach.

Perhaps the most notable aspect of working at Emmaus is the lack of financial reward. In contrast, it is the financial benefits of employment which most government attention has focussed upon, with a commitment to "make work pay" (Adam et al, 2006; Bewley et al, 2007; DWP, 2009; DWP, 2010).

The evidence from Emmaus, however, suggests that some people at least do want to work, even for very little (or no) financial reward. It is of course not possible to know from this research how typical the Companions were of the wider population - they may well be a self-selecting group who are so willing to work without financial reward. Emmaus Companions are expected to work for a rate of pay that is well below the minimum wage which could lead to accusations of exploitation (an issue raised by one Companion interviewed). However, this is not unique amongst projects offering supported working conditions (Marshall and Macfarlane, 2000). Emmaus being a social enterprise, and giving money (albeit relatively small amounts) to other charities were cited by Companions as contributing to their sense of doing something worthwhile rather than being exploited. Once able to sustain work independently companions can and do leave for jobs elsewhere and better pay.

However Emmaus Communities very rarely have any difficulty in filling spaces and usually have long waiting lists, suggesting that there is no shortage of homeless people who are willing to work in this manner. Increased pressure on the social housing and homeless provision, benefit cuts and the current recession and high unemployment levels all point to there being growing demand for these kinds of projects in coming years.

Financial, psychological and social benefits of work were all considered in this paper, as were the benefits of skills gained of being in eligible for housing designated for certain parts of the workforce. Of these, the psychological benefits of working at Emmaus were by far the most often mentioned by referral agencies, staff and the companions themselves.

Allowing people to work, who lack the means to find work within the paid labour market, has benefits to them in terms of self-esteem, and establishment of a routine, even if the costs of keeping them in employment might mean that they aren't receiving a real wage. The routine that working a full week offers may be beneficial particularly to those with previously chaotic lifestyles associated with the heavy use of drugs or alcohol, or petty crime. Work that is seen to have some social or environmental value, increases people's sense of purpose even if the financial reward is low, especially if the beneficiaries are a group close to the hearts of the workers.

There is also a need for realism about the limited impact of increased earnings on people's ability to house themselves. Emmaus is not able to pay real wages to companions, who rely on Housing Benefit to pay their rents. Some do manage to move on to proper paid work, but not into jobs that pay high salaries and many are too old to get mortgages. The private rented sector might be affordable for some (possibly with help to access it), but the preferred long-term option for most people moving on from Emmaus is social rented housing. The current reforms proposed to rent levels in social housing may mean that this client group remains dependent on housing benefit even when in full time paid employment.

It is also important to acknowledge that some groups are excluded from the Emmaus model: families, retired, mentally ill, severely disabled, or major health problems. These 
groups have very different needs to help them into work, or else need to find non-workbased routes to good health, housing and a sense of community and purpose.

\section{Acknowledgments}

The author would like to thank staff, volunteers, trustees, referral agencies and especially the companions at the Emmaus communities for sharing their views and lives with the research team. Thanks also go to Sanna Markkanen for assistance with this research.

* Correspondence Address: Anna Clarke, Department of Land Economy, 19 Silver Street, Cambridge, CB3 9EP. E-mail: acc44@cam.ac.uk.

\section{References}

Adam, S., Brewer, M. and Shephard, A. (2006) The poverty trade-off: work incentives and income redistribution in Britain. York: Joseph Rowntree Foundation and The Policy Press.

Anderson, I. and Christian, J. (2003) Causes of Homelessness in the UK: A dynamic analysis. Journal of Community \& Applied Social Psychology, 13, 105-118.

Anderson, I. and Tulloch, D. (2000) Pathways through homelessness: A review of the research evidence. Homelessness Task Force Series. Edinburgh: Scottish Homes.

Atherton, I. and McNaughton Nicholls, C. (2008) 'Housing First' as a means of addressing multiple needs and homelessness. European Journal of Homelessness, 2, December 2008.

Anderson, I. (1994) Access to Housing for Low Income Single People York. York: Centre for Housing Policy, York University.

Battye, F., Bishop, B., Harris, P., Murie, A., Rowlands, R. and Tice, A. (2006) Evaluation of Key Worker Living. London: Department for Communities and Local Government.

Bewley, H., Dorsett, R. and Haile, G. (2007) The Impact of Pathways to work: DWP research report No 435. London: Department for Work and Pensions.

Carter, M. (2007) Towards an ESRC research programme on multiple exclusion homelessness. London: Homeless Link.

Clapham, D. (2003) Pathways Approach to Homelessness Research. Journal of Community \& Applied Social Psychology, 13, 119-127.

Clarke, A., Markkanen, S. and Whitehead, C. (2008) Evaluating Success: An economic evaluation of Emmaus Village Carton. Cambridge: Emmaus UK.

CLG (2008) Expanding Choice, Addressing Need. London: Communities and Local Government.

DCLG (2007) Evaluation of the Single Regeneration Budget: A Partnership for Regeneration-The Final Evaluation. London: Department for Communities and Local Government.

Dewson, S., Caseboourne, J., Darlow, A., Bikerstaff, T., Fletcher, D., Gore, T. and Krishnan, S. (2007) Evaluation of the Working Neighbourhoods Pilot: DWP Research Report No 411. London: Department for Work and Pensions.

Dorling, D. (2009) Unemployment and Health. BMJ 2009, 338, b829. 
Dorsett, R. (2008) Pathways to Work for New and Repeat Incapacity Benefit Claimants: Evaluation synthesis report. DWP Research Report No 525. London: Department for Work and Pensions.

DWP (2008) No-one written off: reforming welfare to reward responsibility. London: Department for Work and Pensions.

DWP (2009) Building Britain's Recovery: Achieving Full Employment. London: Department for Work and Pensions.

DWP (2010) 21st Century Welfare. London: Department for Work and Pensions.

ERS (2005) Effective Interventions to tackle worklessness: A review of the evidence. London: ERS.

FEANTSA (2007) Multiple barriers, multiple solutions: Inclusion into and through employment for people who are homeless in Europe. National Report United Kingdom - Annual Theme 2007. European Commission.

Feinstein, L. (2008) The public value of social housing: a longitudinal analysis of the relationship between housing and life chances. London: The Smith Institute.

Feldman, L. (2006) Citizens Without Shelter: Homelessness, Democracy, and Political Exclusion. Cornell University Press.

Fitzpatrick, S., Kemp, P. and Klinker, S. (2000) Single Homeless: An overview of research in Britain. York: Joseph Rowntree Foundation.

Fletcher, D., Gore, T., Reeve, K. and Robinson, D. (2008) Social Housing and Worklessness: Key Policy Messages. DWP Research Report No 482.

Fletcher, D., Gore, T., Reeve, K. and Robinson, D. with Bashir, N., Goudie, R. and O'Toole, S. (2008b) Social Housing and Worklessness: Qualitative Research Findings. DWP Research Report No 521.

Fusco, S. (2005) Client Record Statistical Update. St Andrews: Supporting People Client Record Office and University of St Andrews.

Gervais, C. and Rehman, H. (2005) Causes of Homelessness amongst Ethnic Minority Populations. London: Communities and Local Government.

Gregory, J. (2009) In the Mix: Narrowing the gap between public and private housing. London: Fabian Society: Policy Report 62.

Hasluck C, Green A and Adam D (2008) Evaluating City Strategy: Key messages from the First National Evaluation Update. Institute for Employment Research. Warwick: University of Warwick.

Hills, J. (2007) Ends and means: The future roles of social housing in England : CASE report 34. London: London School of Economics.

HM Treasury (2010) Budget 2010. London: Stationary Office.

Leeds Metropolitan: Policy Research Institute (2007) Towards Skills for Jobs: 'What Works' in Tackling Worklessness? London: Learning and Skills Council.

Lovatt, R. et al. (2004) Research Report IX: Emmaus UK: Building on Success: En Economic Evaluation of and Emmaus Community. Cambridge: Cambridge Housing and Planning Research, University of Cambridge.

Mackenzie, D. (2003) Homeless Careers: Pathways in and out of homelessness. Swinburne and RMIT Universities.

Macknee, C. and Mervyn, J. (2002) Critical Incidents that Facilitate Homeless People's Transition off the Streets. Journal of Social Distress and the Homeless, 11, 4.

Mathers, C.D., Schofield, D.J. (1998) The health consequences of unemployment: the evidence. Med J Aust 1998, 168, 178-83.

May, J. (2000) Housing Histories and Homeless Careers: A Biographical Approach. Housing Studies, 15, 4, 613-638. 
Meadows, P. (2006) What works with tackling worklessness? London: London Development Agency.

Mohan, J. (2002) Geographies of welfare and social exclusion: dimensions, consequences and methods. Progress in Human Geography, 26, 1, 65-75.

ODPM (2003) More Than a Roof: a report into tackling homelessness, March 203. London: Office of the Deputy Prime Minister.

Pawson, H. (2007) Local Authority Homelessness Prevention in England: Empowering Consumers or Denying Rights? Housing Studies, 22, 6, 867-883.

Paylor, I. (1995) Housing Needs of Ex-Offenders. Avebury Publishing Co.

Percy-Smith, J. (ed) (2000) Policy Responses to Social Exclusion: Towards Inclusion? Open University Press.

Pleace, N. (2008) Effective Services for Substance Misuse and Homelessness in Scotland: Evidence from an international review. Edinburgh: Scottish Government.

Quilgars, D. and Anderson, I. (1997) Addressing the problem of youth homelessness and unemployment: the contribution of foyers, in: R. Burrows, N. Pleace, D. Quilgars (eds) Homelessness and Social Policy. London: Routledge.

Randall, G. and Brown, S. (2002) New Lives: An independent evaluation of Emmaus Communities in the UK. Cambridge: Emmaus UK.

Reeve, K., Casey, R. and Goudie, R. (2006) Homeless Women: Still being failed yet striving to survive. London: Crisis.

Richie, H., Casebourne, J. and Rick, J. (2005) Understanding workless people and communities: A literature review. London: Department of Work and Pensions: Research Report No 255.

Robinson, D. (2008) Social Housing and Worklessness, In: Fitzpatrick, S. and Stephens, M. (eds), The future of social housing. Shelter.

Sanderson, I. (2006) Worklessness in Deprived Neighbourhoods: A Review of Evidence. London: Department for Communities and Local Government.

Singh, P. (2005) No Home No Job: Moving on from transitional spaces. London: Off the Streets and Into Work.

Smith, J. with Akpadio, S., Bushnaq, H., Campbell, A., Hassan, L. and Pal, S. (2008) Valuable Lives: Capabilities and Resilience amongst Single Homeless People. London: Crisis.

Stein, M., Pinkerton, J. and Kelleher, P. (2000) Young people leaving care in England, Northern Ireland, and Ireland. European Journal of Social Work, 3, 23 -246. 